\title{
The Organization and Merchants Ethnicity of the Greek Companies in Transylvania in the Late 18th Century and Early 19th Century
}

\author{
Bogdan E. Anagnastopol \\ Babes Bolyai University, Cluj Napoca, Romania
}

\begin{abstract}
.
In Transylvania, there were two of the most important Greek centers dealing with the trade of oriental goods from the Levantine area to Central Europe, since the last decades of the Byzantine Empire. The organization of these merchants into trading companies came as a natural consequence of the trade relations that took place on the East-West route. The cities where these merchants settled in Transylvania were Sibiu and Brasov, but some Greek merchants carried out economic activities in Cluj, Alba Iulia, or Oradea as members of the Greek Companies in Sibiu and Brasov. As a result of the privileges they enjoyed over time, these companies developed progressively, and through the power to practice justice within the organization, they enjoyed legal autonomy. The organization of the companies allowed the preservation of the ethnic character of the merchants, by setting up Greek schools and churches, they practiced democracy in the election of leaders and offered support to the Enlightenment movement to gain freedom from the Ottomans. Although their name is the Greek Company, the ethnic origin of the members is much broader. Until 1783, merchants were Greeks from Macedonia or Greece, and after that date, all merchants from the Ottoman Empire who wanted to escape Ottoman pressure were allowed to join the company. The largest number of Greek families in Transylvania was recorded immediately after the revolutionary struggles of Filiki Eteria in Drăgășani and Bucharest. Following the defeat suffered by them, the Greeks took refuge in Brasov and Sibiu, in an attempt to escape the Ottoman repressions.
\end{abstract}

Keywords: Greek merchants, Transylvania, Greek ethnics, Greek Revolution, Merchants organisation

\section{Introduction}

In the context of the 200th anniversary of the Greek Revolution (1821), the study of the Greek diaspora is back today, out of the desire to respond to the problems of the external network that was the basis for achieving this national goal. An important role in this struggle was played by the Hellenistic centers in Brasov and Sibiu, cities where the presence of the Greeks has its origins in the last decades of the Byzantine Empire (Karathanasis, 2003) and which materialized in the seventeenth century in the formation of trading companies in Sibiu ${ }^{1}$

${ }^{1}$ See Tsourka-Papastathi, Compagnies grecques, p. 420 
(1636) and Brasov $^{2}$ (1678). The organization of these companies has undergone several structural changes from a legal and ethnic point of view over time, the most significant change taking place between 1770 and 1791 when based on the concessions offered by Maria Theresa (1775 and 1777) and the privileges offered by Joseph II (1783), offered greater freedom to Greek traders. These privileges also offered the opportunity to receive in the Company people from any part of the Ottoman Empire, not only those from Greece and Macedonia (Danielopolu, 1996), allowing other ethnic groups to join Greek companies in Transylvania. The next important moment in the development and ethnic expansion of the Companies was the wave of Greek refugees in Transylvania from 1800-1802, who received support from the Greeks in Brasov and Sibiu before the Austrian authorities to enter the Company with full rights.

Studies on the organization Greek companies in Transylvania have their origins back in their existence when in 1820 appeared a brochure with 6 chapters written in Hungarian and Romanian which presented the history of the company and economic activity between 1591 and 1771 (Danielopolu, 1996), and through which the Greek merchants requested the acceptance in the Company of those who came to Transylvania between 1800 and 1802. The scientific study of this Hellenistic center in Transylvania can be considered to have begun with the publication of the volume of Greek documents in the company's archive, of the famous historian Nicolae Iorga in 1932. This work by Nicolae Iorga comes as a result of the importance it assigns to the Greek Companies of Brasov and Sibiu since 1921, when it drew attention to the economic role they played in Austrian economic policy and how Greek, Bulgarian and Romanian traders bring oriental goods and sell them in Wallachia (Danielopolu, 1993). Among the most important studies on the organization of Greek companies in Transylvania, we mention those of Olga Cicanci who extensively presented the organization of these companies until the middle of the 18th century (Cicanci, 1976), legal status (Cicanci, 1979), the original codex of the Sibiu Company (Cicanci, 1981) and the commercial activities along with the form of organization of these companies (Cicanci, 1985). For the ethnic structure, valuable information can be found in Cicanci's work published in the Memoirs of the Department of Historical Sciences of the Romanian Academy (Cicanci, 1979). To these studies are added those of Cornelia Papacostea-Danielopolu which presents the organization of the Greek Company in Brasov between 1777 and 1850 (Danielopolu, 1973) and the chapter on Greek Companies in Transylvania in the volume Greek Communities in Romania in the 19th century (Danielopolu, 1996). To these are added those of Despina Tsourka Papastathi about the Greek company from Sibiu published in Balkan Studies (Papastathi, 1982), the study on the fall of Greek companies from Transylvania (Papastathi, 1988) and the volume Compania Comercială Sibiu published in Romania in 2016, translation from the Greek language by Olga Cicanci after the volume published in Thessaloniki in 1994 (Papastathi, 2016). In more recent studies, Athanasios Karathanasis presents Greek companies in Transylvania in the volume Hellenism in Transylvania, focusing mainly on cultural activities (Karathanasis, 2003) and the doctoral thesis of Ruxandra Moașe Nazare which thoroughly documents the society, education and professional techniques of Greeks in Transylvania (Nazare, 2010) and also in the study of the Greek merchant's activities in the Austrian economic context (Nazare, 2004).

${ }^{2}$ See Cicanci, Companiile, p. 23 


\section{Organization of the Greek Companies in Transylvania}

The establishment of Greek trading companies in Transylvania favoured trade with the East (Orient) of the Habsburg Empire. Although at the beginning of the 17th century in Transylvania were another two Levantine trading companies, the Austrian Eastern Company (1719) and the Timisoara Trading Company (1723), they failed to maintain contact with the Orient. Among the reasons why they failed, are the lack of knowledge of the current languages used with the Orient but also the culture of these peoples (Karathanasis, 2003), and how they were organized. Taking into consideration these and the long relationship of the Greek merchants from Transylvania with the Levantine space, it is important to see the legal, administrative organization and the external relations that these Companies from Brasov and Sibiu had.

\subsection{Juridical organization}

The organization and operation of the Company is based on the company's policy. It was first written in Sibiu in 1655 by the head of the Company ${ }^{3}$ and includes laws, decisions and regulations. This condition was changed over time according to the privileges they received from the Emperors of Austria. These privileges were 1) Rakoczi's Decree of 1636 based on which Greek companies were established; 2) The privilege of 1701 which regulated the composition of the Company Court and the appeal procedure and the appeal to a higher court ${ }^{4}$; 3) The Decree of Emperor Leopold of 1707; 4) The privilege of 1777 issued by Maria Theresa, which brings several legal changes; 5) The edict of Emperor Joseph II of 1783, which allows them to register in the Company merchants from the Ottoman Empire, not only from Macedonia or Greece. If one or more members violated this regulation, the Company had the right to judge their situation at the general meeting. The right to practice justice is a fundamental element in the organization of Greek companies in Transylvania and which lost its power following the Privilege of 1777. As a result, the Company received some benefits, but also certain limitations. Thus, the members of the company could, among other things: a) sell products of any kind in retail and wholesale, in the houses they owned in Transylvania, b) outside the houses they could sell only in market fairs ${ }^{5}$ (Tsourka-Papastathi, 2016), c ) members of the Greek company could obtain a passport, based on proof from the President of the Company. The most significant legal change in the Privilege of 1777 was the decision to remove from the authority of the Company the resolution of problems regarding the exchange of money and the conciliation of loans (Tsourka-Papastathi, 2016). Through this decision, the legal activity was substantially limited, the resolution of economic problems between traders having the highest volume from a legal point of view, thus weakening the power of the Company.

${ }^{3}$ President and notary Panu Ioanu, followed by Nicolciu Hristianitsis and Ianache Adam; for more details see Karathanasis, A., Une lettre de la deuxieme moitie du dix-huitieme siecle, originaire d Albanitochori, Primier Symposium greco-bulgare, ed. I.M.H.A, Thessaloniki, 1980, p. 177-186

${ }^{4}$ These regulations were preceded by the decisions of the governor of Transylvania from 1694 (litterae donationales) and by the Imperial Treasury of Transylvania from 1698 (litterae patentales), see Tsourka-Papastathi, Compania Comercială greacă din Sibiu, 2016, p. 78

${ }^{5}$ According to the Privilege of 1701 , they could sell goods anywhere 


\subsection{Administrative organization}

From an administrative point of view, the Company was led by a President (leader, "proestos", "jude") with a term of 2 years, and in his absence, his place was replaced by the trustee ("epitrop"). The trustee paid for the parish priests and teachers of the Greek school and church $^{6}$. They presented the balance of the activity for periods of 1,2 , or 3 years ${ }^{78}$, and were sometimes called to present the activity before the city judge ${ }^{9}$. For the correct application of local laws and internal regulations, 12 foremen were elected from among the members. They judged civil and commercial proceedings among the Company in the first instance (Karathanasis, 2003). The taxes were collected by those who held the position known as "haragiar" or "foolog", and who had the responsibility to record these incomes in the registers. Mediation between the members of the Company was ensured by the priest brought from various places of Greece, to serve in the Greek churches in Brasov and Sibiu. Membership of the Company was obtained by those merchants who paid a fee set by the head of the Company, get registered in the Membership record. From 1701 they needed the prior approval of the head of the company, and from 1777 was required the approval of the Transylvanian government. The members were divided into two categories, ordinary members and extraordinary members. For the ordinary people, the conditions were that they should not be indigenous, to trade in imports, and to have a residence in Transylvania. The extraordinary members were those who did not have the right to reside or live in Transylvania, to carry out import trade in Transylvania, and to pay the endowment to the Company. Membership was lost either by withdrawal or by its exclusion by the General Assembly. The supreme governing body of the Greek Companies was the General Assembly, which attempted to take its decisions (related to the social, economic, and administrative structure) to ensure equality and taxation of merchants based on income. This type of organization of the Company has a strong traditional character from the Greek space (Danielopolou, 1996).

\subsection{External relations}

The interests and requirements of the Company were represented by an Ambassador of merchants, who ensured diplomatic relations and the communication of decisions between the Greek Company and the local and Imperial authorities. In addition to the relationship with the authorities, the Greeks in Transylvania had strong economic, cultural, and political relations with other Hellenistic centers in Europe, such as those in Venice, Trieste, Vienna, Leipzig, Odessa $^{10}$, etc. In relation to the Orient, Greek companies in Transylvania were often supported by wealthy merchants in Turkey who offered them loans for certain businesses. In this sense, a merchant from Turkey writes to Nicola Coclangi from Brasov, that after the war with France,

\footnotetext{
${ }^{6}$ BAR*, fond Bis gr., ms. 100/ MDCCXLVII, 1801, Brașov, * BAR = Library of the Romanian Academy, manuscript

${ }^{7}$ BAR, fond Bis gr., ms. 107/ MDCCXLVII, 1801, Braşov

${ }^{8}$ BAR, fond Bis gr., ms. 17/ MDCCXLIX, 1803, Brașov

${ }^{9}$ BAR, fond Bis gr., ms. 10/ MDCCXLI, 1801, Brașov

${ }^{10}$ BAR, fond Bis gr., ms. 78/ MDCCLXXVII, Odessa
} 
he cannot offer him the requested credit $^{11}$. Similar to credit, there were agreements with merchants in Vienna and Constantinople, who settled the business.

\section{The ethnic structure of the Greek Companies in Transylvania}

As Danielopolou remarked, Greek companies in Transylvania had an organization with a strong traditional Greek character. As we presented earlier, starting with 1783 the members of these companies were Greeks from all over the Ottoman Empire ${ }^{12}$, so it is necessary to understand what the term Greek means. In the 17th century, in the Transylvanian documents, we find Balkan merchants registered with information about their name and the place of origin, but without being able to establish the ethnicity (Cicanci, 1981).

According to Nicolae Iorga, the Greek companies in Transylvania had at first a Balkan character, without having a national character. By using the Greek language as a channel of communication, they were called Greeks, even if among them were Slavs or Romanians. Also, Nestor Camariano shows that among the Sibiu Company members there were Romanians, including from Macedonia and Bulgarians who felt closer to the Greeks, for economic reasons (Camariano, 1943). The same information is detailed by Cornelia Papacostea Danielopolu and Lidia Demeny ${ }^{13}$. According to archival documents, in Brasov in 1777, the Greek Company had 46 members with origins in Macedonia (Melnik, Moscopole), Epirus, Wallachia, Transylvania, and Bulgaria ${ }^{14}$. After the process of reorganization and entry into the company of new members, in 1800, the Greek Company in Brasov had 23 Romanians, 16 Greeks, 10 Bulgarians, and 2 Aromanians (Danilopolu, 1996). To have an overview of the number of ethnic groups in Transylvania, we will present demographic data assembled by Al. Csetri and Șt. Imreh. In this demographic study that includes the number of taxpayer families in the period 1766-1821, the situation is as follows:

Table 1. Number of ethnic groups in Transylvania between 1766-1821

\begin{tabular}{|l|l|l|l|l|l|l|l|l|l|}
\hline Ethnicity & 1766 & 1776 & 1785 & 1791 & 1795 & 1805 & 1808 & 1815 & 1821 \\
\hline Greeks & 74 & 100 & 94 & 103 & 118 & 73 & 130 & 57 & 309 \\
\hline Armenians & 191 & 167 & 203 & 246 & 235 & 343 & 366 & 394 & 339 \\
\hline Bulgarians & 49 & 38 & 31 & 31 & 22 & 42 & 19 & - & 17 \\
\hline Jews & 194 & 241 & 304 & 314 & 356 & 484 & 544 & 553 & 555 \\
\hline
\end{tabular}

Source: (Moaşa-Nazare, 2010)

These data show only a part of the ethnics settled in Transylvania, but even so, we can observe a significant increase of the Greeks in Transylvania in the year of the Revolution of 1821, year in which after the battles between Romanian troops and the Sacred Band of Filiki

${ }^{11}$ BAR, fond Bis gr., ms. 70/ MDCCLXXIII, 1819, Moscopol

12 as described by the Edict of Emperor Joseph II

13 see Grecs, Roumains, Bulgares et Grecs dans la Compagnie grecque de Brasov (1777-1850), lucrare apărută la Bulletin de 1Association Internationale d Etudes de sud Est Europeen în 1972

${ }^{14}$ Arh. Bis. Sf. Tr. Br., parh. 1 Tabelul Conscripției din 1777 (The archives of the Greek church of the Holy Trinity in Brasov) 
Eteria, many the Greeks from Wallachia took refuge in Transylvania. Among the Greek refugees in Sibiu and Brasov are boyar families, high Greek dignitaries, fighters of the sacred battalion, Greek teachers from the Wallachia, and merchants. As a parallel, in the same period, in Odessa in 1795 lived 62 families from the Greek archipelago or other areas of Greece (Arsh, 1970) to which were added another 27 Greek merchants (Herlihy, 1979) reaching to represents $10 \%$ of the city's population (Arsh, 1970). While in Mariupol (today Zhdanov) in 1816 lived 11,500 Greeks (Arsh, 1970).

\section{Conclusion}

Observing the historical course, the marketed products, and financial stability, it is important to emphasize the importance of these Greek companies from Transylvania. Not only did they manage to survive over time, compared to Austrian and Romanian companies in Transylvania, but they also became culturally involved by setting up schools and churches.

These successes were based on the administrative organization and the benefits that these companies received from the Emperors of Austria. The fundamental element being the right to practice justice.

At the end of the 18th century, many of these benefits diminished, especially the restriction of economic and conciliating processes, which led to the weakening of companies. The economic crisis around 1815, immediately after the end of the Napoleon War, which strongly affected the Greek Companies, also contributed to this weakening, as evidenced by the low number of those who remained in Transylvania at that time.

After the edict of Joseph II, the number of merchants increased and the ethnic composition expanded. The companies came to have a multiethnic character, in which the language of circulation was the Greek language and the Greek Orthodox as religion. Thus, Greek companies have a much broader ethnic representation, the Greek term being an ethnonym, which suggests a person's from Balkans belonging to the Greek Orthodox religion.

\section{Acknowledgment}

This work was supported by the project "Quality, innovative and relevant doctoral and postdoctoral research for the labour market": POCU/380/6/13/124146, project co-financed by the European Social Fund through The Romanian Operational Programme "Human Capital" 2014-2020.

\section{References}

Arsh, G. L., 1970, Eteristskoe dvizhenie v Rossii. Osvoboditel'niaia bortba grecheskogo naroda v ntachale XIX v. i russko-grecheskie sviaz, Nauka, Moscow

Camariano, N., 1943, L'organisation et l'activité culturelle de la Companie des marchands grecs de Sibiu, Balcanici 6

Cicanci, O., 1976, Le statut juridique et les règlements de fonctionnement des companies greque de Transylvanie (1636-1746). RESEE XIV, pp. 477-497 
Cicanci, O., 1979, Structura etnică a companiilor comerciale din Transilvania, Memoriile Secției de Științe Istorice ale Academiei, Seria P, IV, București, pp. 37-50.

Cicanci, O., 1981, Companiile grecești din Transilvania și comerțul european în anii 16361746, Ed. Academiei Republicii Socialiste România,București

Cicanci, O., 1981, Un codex inèdit de la Compagnie de Sibiu, $R R H X X$, pp. 673-681

Cicanci, O., 1985, Formes d'organisation de l'activité commerciale dans le Sud-Est de L'Europe aux XVIIe et XVIIIe siècles jusqu'au commencement du XIXe siècle, Actes du Ile Colloque international d'Histoire Economies mèditerranéennes: èquilibres et intercommunications, XIIIe-XIXe siècles, t.I, Athens, pp. 77-90

Danielopolu, C. P., 1973, L'organisation de la Compagnie Greque de Brasov (1777-1850), Balkan Studies, 14, pp. 313-323

Danielopolu, C. P., 1996, Organizarea și viața culturală a companiei grecești din Brasov, Ed. Omonia, București.

Herlihy, P. (1979). Greek Merchants in Odessa in the Nineteenth Century. Harvard Ukrainian Studies, 3/4, pp. 399-420

Karathanasis, A. E., 2003, Elenismul în Transilvania, București, Ed. Omonia, București

Limona, D., 1958, Catalogul documentelor grecești din Arhivele Statului din orașul Brașov, vol. I, Bucuresti.

Nazare, R. M., 2003, Rolul "grecilor" în orașul Sibiu și Brasov la sfârcşitul secolului XIX- lea, Historia Urbana 11/1-2, pp. 153-168.

Nazare, R. M., 2004, Politica economica austriaca si negustorii greci din Transilvania, Anuarul Institutului "A.D. Xenopol", Iaşi

Nazare, R. M., 2010, Sub semnul lui Hermes și al lui Pallas, Editura Academiei Române, București

Tsourka-Papastathi, D. I., 1982, À propos des Compagnies greques de Transylvanie à Sibiu et Brasov, Balkan Studies, 23, pp. 421-431

Tsourka-Papastathi, D. I., 1988, The decline of the Greek Companies in Transylvania, War and Society in East Central Europe, vol. XXIII, pp. 213-218

Tsourka-Papastathi, D. I., 2016, Compania Comercială Greacă din Sibiu, Ed. Omonia, București 